\title{
Late Quaternary coastal landscape morphology and evolution of the Maltese Islands (Mediterranean Sea) reconstructed from high-resolution seafloor data
}

\author{
FEDERICA FOGLINI $^{1 *}$, MARIACRISTINA PRAMPOLINI ${ }^{1,2}$, AARON MICALLEF $^{3}$, \\ LORENZO ANGELETTI ${ }^{1}$, VITTORIA VANDELLI ${ }^{2}$, ALAN DEIDUN $^{3}$, \\ MAURO SOLDATI ${ }^{2} \&$ MARCO TAVIANI $^{1}$ \\ ${ }^{1}$ National Research Council, Institute of Marine Sciences, Via Gobetti 101, \\ 40129 Bologna, Italy \\ ${ }^{2}$ University of Modena and Reggio Emilia, Department of Chemical and Geological Sciences, \\ Via Campi 103, 41125 Modena, Italy \\ ${ }^{3}$ University of Malta, Department of Geosciences, Msida, MSD 2080, Malta \\ *Corresponding author (e-mail: federica.foglini@bo.ismar.cnr.it)
}

\begin{abstract}
The current strong motivation to explore those traces of the archaeological and prehistoric human heritage that presently lie submerged on the continental shelf requires large-scale and precise underwater mapping. One Mediterranean sector deserving particular attention is the Sicily Channel, which is critical for a better understanding of the Africa-Europe migratory routes and early civilization patterns due to its large expanses of shallow seabed that were partially or totally exposed at times of lower relative sea levels. We have focused our attention on the submerged continental margin of the Maltese archipelago. A detailed bathymetric map is here presented, and is discussed in terms of features interpretable as former subaerial landforms and inundated by sealevel rise following the Last Glacial Maximum lowstand at approximately $-130 \mathrm{~m}$. Our datasets combine multibeam surveys, Light Detection And Ranging (LiDAR)-derived digital terrain models (DTMs), Chirp sub-bottom profiler records and bottom samples acquired between 2009 and 2012. The main features identified are former river incisions, alluvial plains, karst landscapes (sinkholes, limestone plateaus), slide deposits and palaeoshorelines. This study provides a detailed topographical reconstruction of the palaeolandscape of this key region that is relevant to any future archaeological exploration of the Maltese offshore area.
\end{abstract}

At present there is a strong appreciation of the key fact that a substantial portion of our archaeological heritage lies under water as a consequence of the late Pleistocene post-glacial sea-level rise (Flemming 1969; Bailey \& Flemming 2008; Benjamin et al. 2011). This fact is the motivation for a steadily growing research field that integrates advances in both scientific knowledge and marine technology. Although most research effort was, and still is, directed towards archaeological investigation at relatively shallow depths via scuba-diving (Benjamin 2010), progress in offshore technology and a refreshing transdisciplinary scientific attitude is pushing our quest for questions and answers offshore and deeper. One inescapable prerequisite to contribute valuable underwater geo-archaeological and prehistoric data is the precise mapping of such drowned landscapes (Bicket 2011; Westley et al. 2011). This is not always a simple task because it requires the evaluation of the degree of marine modification undergone by the former landscape in response to a variety of processes associated with marine transgression. Nevertheless, the current boom in multibeam bathymetric mapping is providing the very basic tool required for rapid reconstruction of extensive areas of the seafloor with the accuracy required for geo-archaeological and prehistoric investigations (Westley et al. 2011; Micallef et al. 2013).

Because of its geographical position, the Maltese archipelago affords a natural bridge between Africa and Europe (Bowen-Jones et al. 1961; Cassar et al. 2008), thus assuming a central role in prehistoric human migratory routes and the expansion of settlements in the Mediterranean Basin (cf. Antonioli et al. 2014). Crucial to better unravelling such a function is the reconstruction of former landscapes that have been inundated by the post-glacial sealevel rise. With this in mind, a detailed submarine mapping programme has been undertaken in recent years to reconstruct the palaeolandscape of the Maltese continental margin. Although mapping of 

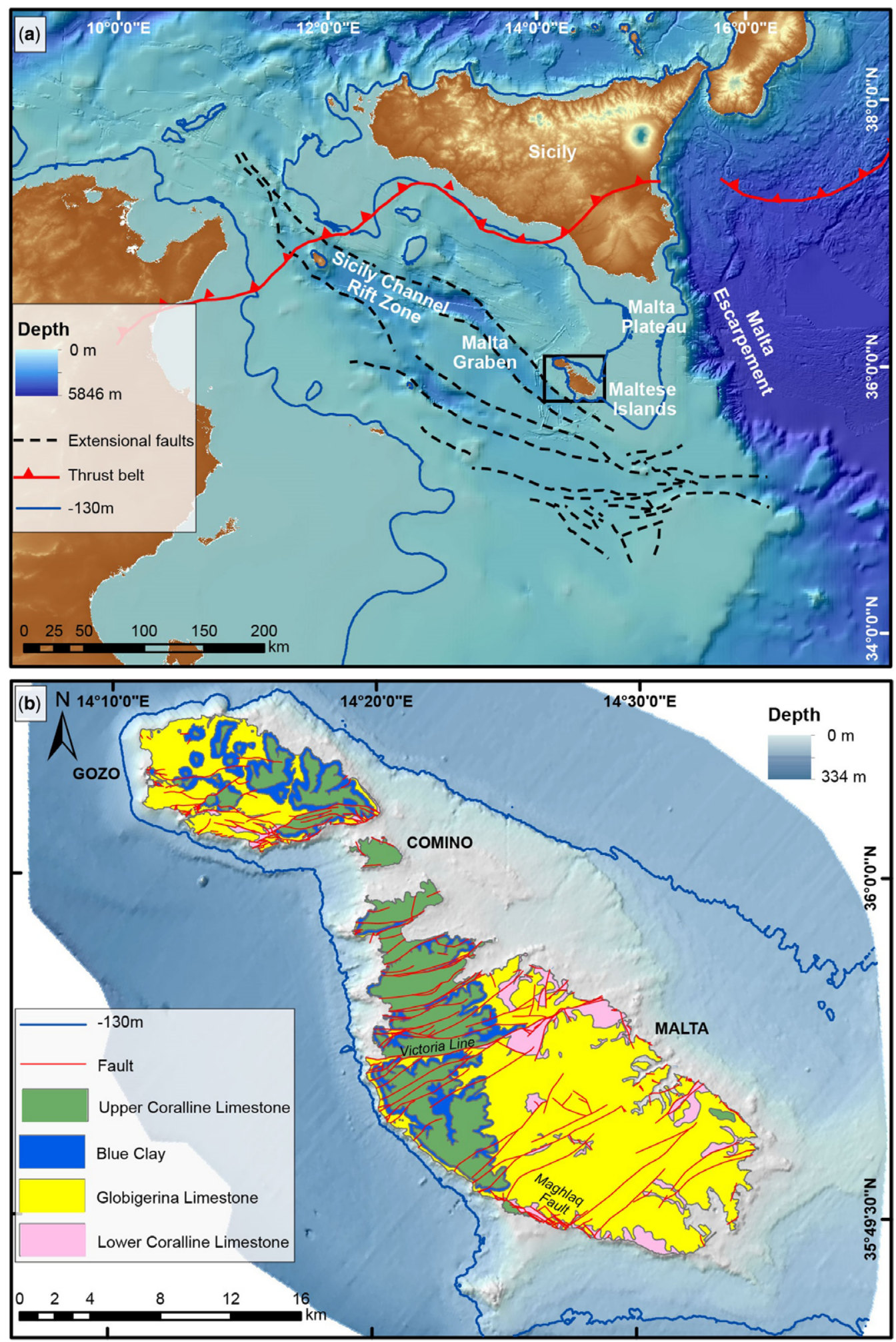
sectors of the Maltese margin is still in progress, the most complete information from the NE, NW and SE portions of this palaeolandscape are presented here. The aim of this chapter is to present an overview of the morphology and evolution of the submerged palaeolandscape of the Maltese archipelago using a variety of seafloor datasets and to offer clues to future geo-archaeological exploration.

\section{Regional setting}

The Maltese archipelago, which comprises the islands of Malta, Gozo, Comino and two uninhabited islands, is located in the Sicily Channel on the Malta-Ragusa Platform, about $200 \mathrm{~km}$ south of the convergent segment of the Europe-Africa plate boundary running through Sicily (BowenJones et al. 1961; Jongsma et al. 1985; Reuther \& Eisbacher 1985; Cello 1987; Argnani 1990; Civile et al. 2010). The backbone geology of the archipelago consists of an Oligo-Miocene marine succession, largely, although not uniquely, consisting of carbonate formations (Pedley et al. 2002). These include: (i) the Lower Coralline Limestone Formation (Chattian); (ii) the Globigerina Limestone Formation (Aquitanian-Lower Langhian); (iii) the Blue Clay Formation (Upper Langhian-Lower Tortonian); (iv) the Greensand Formation (Tortonian); and (v) the Upper Coralline Limestone Formation (Upper Tortonian-Lower Messinian). These units lie almost horizontally across the islands and are affected by two normal fault systems (Dart et al. 1993; Putz-Perrier \& Sanderson 2010). The oldest one is orientated WSW-ENE and its principal lineament is the Great Fault, which, with a displacement of $195 \mathrm{~m}$, divides the Island of Malta into two portions. The most recent fault system is orientated NW-SE, which is parallel to the Pantelleria Rift trend. Its most important fault is the Maghlaq Fault, which outcrops on the southern coast of Malta. This system controls the trend of the western and eastern coasts of the archipelago. The Maltese Islands are located on the northern shoulder of the Malta Graben, which forms part of the Pantelleria Rift. Uplift of this shoulder explains why the archipelago tilts by $4^{\circ}$ towards the NE (Fig. 1).

The tilting, the fault systems and the different mechanical properties of the rocks (limestones v. clays) control the geomorphology of the Maltese Islands (Alexander 1988; Magri 2006; Devoto et al.
2012; Biolchi et al. 2015). In the northern part of the archipelago, the WSW-ENE fault system is responsible for a horst-and-graben structure that extends from the Great Fault to SE Gozo (Illies 1981; Alexander 1988; Devoto et al. 2012). Here, the landscape is characterized by ridges and plateaus made up of Upper Coralline Limestone alternating with valleys locally filled by alluvial sediments. In this area there are several types of coastal landslides: falls of limestone rocks associated with plunging cliffs; lateral spreads and block slides where the Blue Clay outcrops at sea level; and earth flows affecting the clay slopes (Dykes 2002; Farrugia 2008; Magri et al. 2008; Coratza et al. 2011; Soldati et al. 2011; Devoto et al. 2013; Mantovani et al. 2013). These coastal landslides extend well below sea level, often showing larger accumulations of limestone blocks (Prampolini 2013). The locations of the bays, where pocket beaches occasionally occur, correspond to graben between WSW-ENE faults. Shore platforms form where the Globigerina Limestone Formation outcrops, whereas plunging cliffs correspond to thick Lower Coralline outcrops at the shoreline. In Gozo, the landscape is distinguished by an alternation of mesas and hills crossed by a dense and dry drainage network. The NE part of Gozo is dominated by an alternation of boulder scree ('rdum' in Maltese) and shore platforms, while, in the SW part, plunging cliffs comprise the prevailing type of coast (Said \& Schembri 2010). The western coastline of Gozo is marked by largescale sinkholes (Soldati et al. 2013; Galve et al. 2015). In NE Malta, the coast comprises a succession of plunging cliffs and shore platforms (Paskoff \& Sanlaville 1978; Said \& Schembri 2010; Biolchi et al. 2015).

The area south of the Great Fault is largely built up (especially around the harbour area, Sliema, St Julian's Bay) and comprises gently sloping plains of Globigerina Limestone. This formation is very susceptible to marine erosion and weathering, which has resulted in several marine caves, stacks, arches and subcircular bays developing along the coast (Said \& Schembri 2010; Biolchi et al. 2015). In SW Malta, the coastline consists of high, vertical cliffs and shore platforms.

The Maltese Islands are marked by karst features of different size, from dolines to palaeosinkholes (especially in Gozo: Coratza et al. 2012; Soldati et al. 2013; Galve et al. 2015), karst limestone pavements (especially on Lower and Upper Coralline

Fig. 1. (a) Bathymetric map of the Pelagian Platform, central Mediterranean Sea, showing the location of the Maltese Islands and the principal morphostructural features (Smith \& Sandwell 1997; Catalano et al. 2008). The isobath of -130 m represents the coastline during the Last Glacial Maximum (LGM). (b) Map of the main terrestrial geological formations and fault systems of the Maltese Islands (Oil Exploration Directorate 1993) and bathymetric map of the Maltese waters (DTM resolution of $10 \mathrm{~m}$ and vertical exaggeration of $\times 5$ ). 


\section{F. FOGLINI $E T A L$.}

Limestone) and pits (Alexander 1988; Pedley et al. 2002; Magri 2006). The archipelago is also incised by a fluvial system consisting of several 'widien' (wadis) that are orientated SW-NE and that have formed narrow valleys from the 'hinterland' to the coastline (Alexander 1988; Anderson 1997).

A wealth of information is available on global sea-level fluctuations since the Last Glacial Maximum (LGM: e.g. Siddall et al. 2003; Lambeck \& Purcell 2005; Lambeck et al. 2011). Most evidence on sea-level change in the Maltese Islands has been derived from geomorphological, sedimentological, palynological and archaeological markers (e.g. Carroll et al. 2012; Marriner et al. 2012; Pedley 2011; Furlani et al. 2013), but only goes back a few thousand years. In this study, we also use results from Lambeck et al. (2011), who reported estimates of sea-level change for the past $20 \mathrm{ka}$ from the south of Sicily, which is geographically proximal to the Maltese archipelago. The emergence of the Maltese Islands occurred in the early Messinian (Pedley et al. 2002), although in the last $125 \mathrm{ka}$ the archipelago has largely been tectonically stable (Pedley et al. 2002; Galea 2007; Serpelloni et al. 2007; Furlani et al. 2013). The Last Glacial Maximum shoreline of the Maltese archipelago is thus believed to coincide with the $130 \mathrm{~m}$ isobath (Micallef et al. 2013), which is consistent with the figure reported for Mediterranean stable coastlines by Lambeck et al. (2011). This is key to the ensuing geomorphological interpretations of the submerged landscapes of the Maltese Islands.

\section{Materials and methods}

This research has been based on high-resolution multibeam echosounder (MBES) and side-scan sonar data, Light Detection And Ranging (LiDAR) bathymetric data, Chirp sub-bottom profiles and seafloor samples acquired during several oceanographic cruises that surveyed the areas offshore the Maltese archipelago between 2009 and 2012 (Figs $2 \& 3$ ). The datasets cover:

- the NE shelf of the Maltese archipelago, from N Gozo to SE Malta;

- offshore of the NW coast of Malta (from Marfa Ridge to Ras il-Pellegrin);

- offshore of western and northern Gozo.

The seafloor offshore of the NE part of the archipelago was investigated during the cruises of HMS Roebuck (2006), and of R/V Urania and R/V Hercules participating in the MEDCOR (2009), RICS (2010) and DECORS (2011) projects. Multibeam and backscatter data were acquired using Kongsberg Simrad multibeam systems EM710, EM1002 and EM3002D. In 2012, surveys were performed offshore of the NW coast of Malta and Gozo onboard the ISIS catamaran of the AquaBioTech group using the SEA Company interferometric system SWATHplus-L. All systems were coupled with a differential global positioning system (DGPS) and motion sensor unit (MRU), whilst the speed of sound in the water column was measured using a CTD (conductivity, temperature and depth) probe.

The bathymetry data were processed using the software CARIS HIPS and SIPS 7.1, corrected for tidal movements and merged to create digital terrain models (DTMs) of 1-2 m bin size of the seafloor. The DTMs were exported and analysed with ArcGIS 10.

The backscatter data of the NE area of the Maltese archipelago were processed with PRISM (Le Bas \& Hühnerbah 1998), and analysed with the CARIS HIPS and SIPS 'Auto Analyze' tool by applying the Geocoder Engine technology to determine the type of sediment by the angular response (as illustrated in Fonseca \& Calder 2007; Fonseca $\&$ Mayer 2007). Two values of grain size expressed in $\varphi$ were associated with every patch. Side-scan sonar data were acquired with a Klein 3900 system, and processed with CARIS HIPS and SIPS 7.1.

Seafloor samples were collected with a Van Veen grab, and analysed for grain size to validate the backscatter and side-scan sonar data. Grain-size analyses entailed the use of a mechanical sieve for the sand fraction and a sedigraph for the finer fractions. The results were collected and processed using the free software GRADISTAT, which allowed us to obtain a value of $D_{50}$ associated with a descriptive term for each sample. These data were compared with the results of the automatic backscatter analysis.

The LiDAR data cover both the land and sea portions of the northern area of the Island of Malta and of the Dwejra Bay and Dwejra North area on the Island of Gozo. These data were acquired by the AquaBioTech Group through the instrument HawkEye II, a device with a density ranging from $1.7 \times 1.7$ to $3.5 \times 3.5 \mathrm{~m}^{2}$. Seafloor topography data are captured with a data density ranging from 4 to 1 point per $\mathrm{m}^{2}$, typically with an accuracy higher than $15 \mathrm{~cm}$ rms. From these files, a DTM with a $1 \mathrm{~m}$ resolution was derived and used for geomorphological interpretation of areas that were not surveyed with the multibeam echosounder.

\section{Geomorphology of the submerged palaeolandscape of the Maltese archipelago}

The extent of the continental shelf varies considerably within the Maltese archipelago. It is wider in the NE sector, with a maximum width of $7-10 \mathrm{~km}$ offshore of St Paul's Bay, and narrows significantly in the NW area, extending for a maximum of 


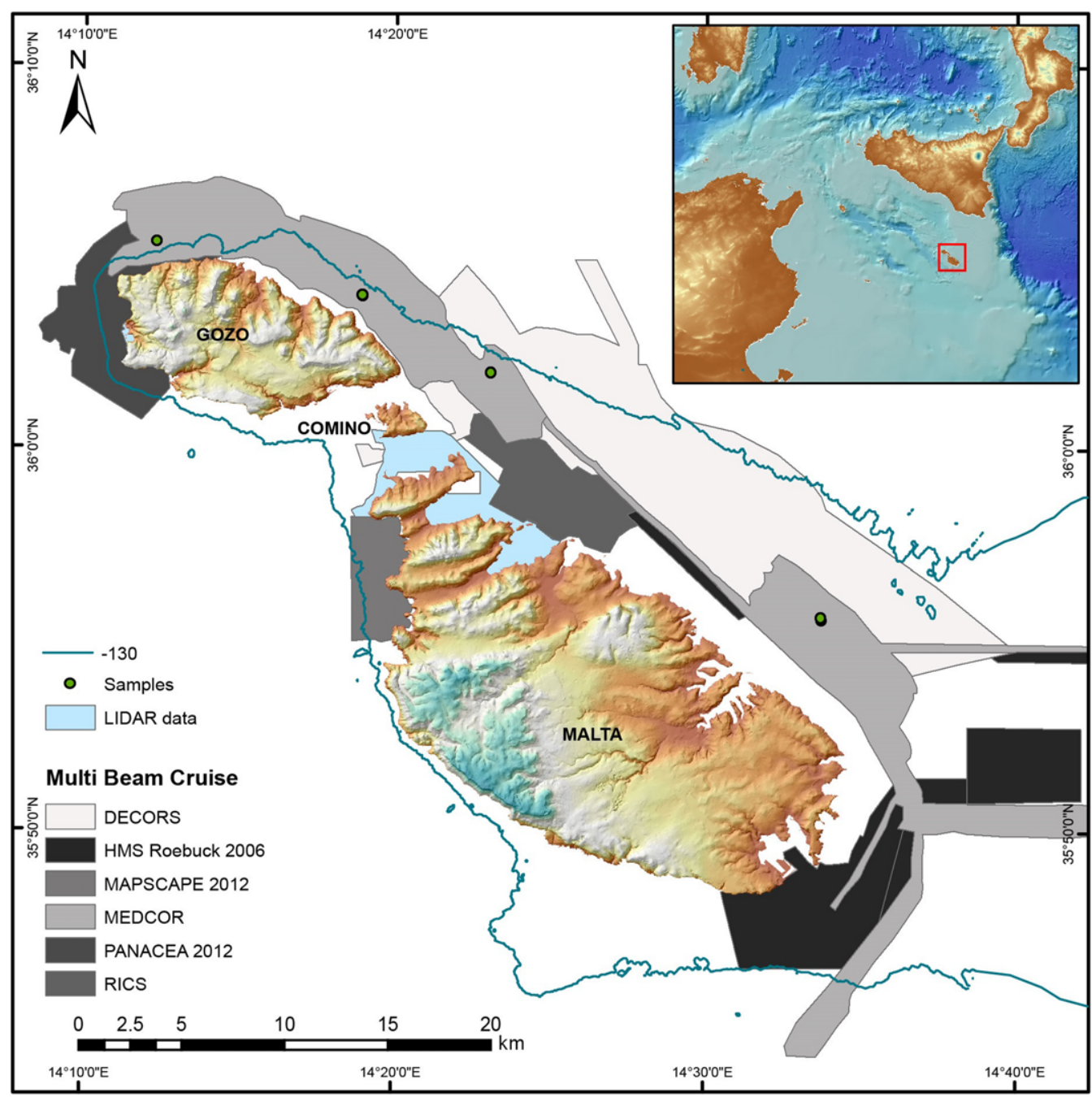

Fig. 2. Spatial coverage of MBES and sample data acquired during the HMS Roebuck, MEDCOR, DECORS RICS10, MAPSCAPE 2012 and PANACEA2012 cruises.

$1.8 \mathrm{~km}$. Along the entire archipelago, the shelf is bounded by a break of slope with a bathymetric depth ranging from 50 to $95 \mathrm{~m}$, and with its base at $120-130 \mathrm{~m}$. From Gozo to Salina Bay (Malta), it is straight, continuous, orientated NW-SE and has a maximum slope gradient of $35^{\circ}$. In the western sector of the archipelago, the break of slope is orientated north-south, and is irregular, discontinuous and has a slope gradient of $20^{\circ}-35^{\circ}$.

The occurrence of the base of the continental escarpment at a depth of 120-130 m substantiates that this feature potentially represents the shoreline of the Maltese archipelago during the LGM, when the parts of the continental shelf now located at a depth of $<130 \mathrm{~m}$ were emerged and affected by subaerial processes (Lambeck et al. 2011; Micallef et al. 2013). On the continental shelf, we observe a wide variety of terrestrial and marine geomorphological features of different origin that were emerged during the LGM: karst features (sinkholes and karst pavement), features related to slope instability (block slides), fluvial features (former river incision and alluvial plains) and coastal features (palaeoshorelines and their deposits). The area downslope of the shelf break is defined by a more uniform, smooth and gently sloping morphology, which is mainly a result of hemipelagic and contouritic deposition (Fig. 4).

The seafloor backscatter data correlate well with the dominant grain size and other compositional 

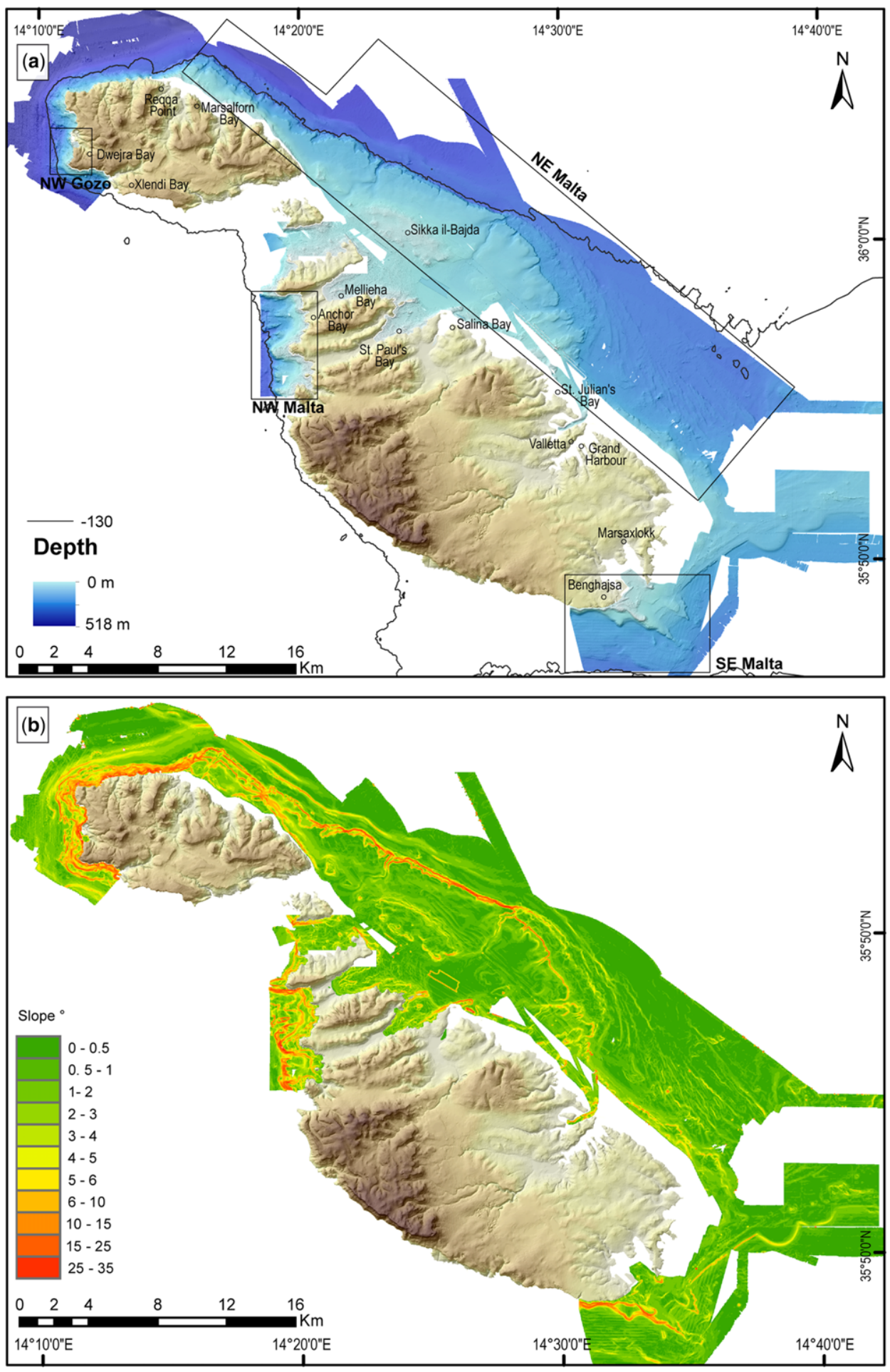

Fig. 3. (a) Bathymetry (grid resolution of $5 \mathrm{~m}$, vertical exaggeration of $\times 5$ ) and (b) slope map derived from MBES data. A DEM of the Maltese Islands with place names is included. 
properties of sediment typology. In fact, a low backscatter corresponds to fine sediment, while a high backscatter matches rocky outcrops and blocks or medium-coarse sediment (Masetti et al. 2010). From such data, it appears that the escarpment marks the boundary between a basin regularly covered by fine sediments (silt or clay) and a heterogeneous shelf, made up of coarse sediment, rocky outcrops and fine sediment. The backscatter was also useful to differentiate and map conspicuous areas of marine vegetation (De Falco et al. 2000), such as the Posidonia oceanica meadows that occur extensively on the NE and NW shelves of the Maltese archipelago (Fig. 5).

\section{Western sector of the submerged palaeolandscape}

\section{NW Gozo}

In the area offshore of NW Gozo, we observed a $\mathrm{N}-\mathrm{S}$-orientated escarpment that has a slope gradient of $20^{\circ}-35^{\circ}$, and a depth ranging between 90 and $130 \mathrm{~m}$. The escarpment is characterized by the presence of marine terraces and has been extensively eroded in the western part, off Dwejra Bay, as indicated by the occurrence of some large remnant blocks (relict features: Swift et al. 1971).

On the continental shelf, which greatly narrows from $1200 \mathrm{~m}$ in the west to $300 \mathrm{~m}$ in the north, we detected two subcircular depressions in Dwejra Bay and Dwejra North (400 and $330 \mathrm{~m}$ in diameter, respectively). Dwejra Bay is a $12 \mathrm{~m}$ deep and flat depression with a rough surface marked by subcircular lineaments. It is bounded seawards by a stack (Fungus Rock) and landwards by subvertical cliffs. Dwejra North is $30 \mathrm{~m}$ deep; its bottom is gently sloping and characterized by an annular structure $120 \mathrm{~m}$ in diameter showing a flat-topped $2 \mathrm{~m}$ relief (Fig. 6).

Based on the assumptions of Pedley (1974), these depressions have been interpreted as caprock collapse palaeosinkholes by Soldati et al. (2013) and Galve et al. (2015). Soldati et al. (2013) asserted that the first stage in the formation of these sinkholes is due to karst dissolution of the Lower Coralline Limestone Formation or, potentially, of the underlying evaporites. Dwejra Bay and Dwejra North could represent the final stage of evolution due to selective erosion, which completely removed the Blue Clay deposits.

\section{NW Malta}

The break of slope at a depth of approximately 25 $50 \mathrm{~m}$ in the NW area of Malta changes orientation from W-E to NNW-SSE in front of Gebel Imbark.
It is indented, has a slope gradient of $15^{\circ}$ and is defined by a number of marine terraces. The base of the deeper marine terrace is located at a depth of around $130 \mathrm{~m}$, while the shallower terraces occur at different depths $(15,49$ and $76 \mathrm{~m})$. These terraces are flat or sloping slightly seawards, and are bounded by a break of slope. They have been interpreted as palaeoshore platforms shaped by wave action during the post-glacial sea-level rise, being morphologically similar to modern shore platforms occurring along the coastline.

In places, the break of slope is interrupted and the shelf is connected to the basin by a slope of $3^{\circ}$. Isolated reliefs, such as the one identified off Ghadira Bay (orientated WSW-ENE, $1124 \mathrm{~m}$ long and $237 \mathrm{~m}$ wide), might be remnant blocks derived by selective subaerial erosion of an Upper Coralline Limestone block with respect to more erodible underlying lithologies in the Mellieha Graben.

The most relevant features of this area are represented by rocky blocks occurring down to a depth of $50 \mathrm{~m}$ and often partially covered by Posidonia oceanica. Their density is conspicuous, especially in the proximity of coastal landslides or plunging cliffs, which are often affected by rock falls. Offshore of Anchor Bay, Bajda Ridge and Il-Qarraba, the rocky block accumulations extend up to $300-$ $550 \mathrm{~m}$ from the coastline, reaching a depth of 20 $45 \mathrm{~m}$, and the rocky blocks range in size from a minimum of $10 \times 8 \mathrm{~m}^{2}$ to a maximum of $38 \times$ $42 \mathrm{~m}^{2}$ (Prampolini 2012, 2013). They seem to be related to the active terrestrial lateral spreads and block slides identified along the coast (Devoto et al. 2012, 2013; Devoto 2013; Mantovani et al. 2013). These submarine block-slide accumulations have been interpreted as resulting from active coastal landslide processes, and document their substantial extension under water. In fact, it is likely that such submerged and outcropping deposits pertain to a single landslide system active since the time when sea level was significantly lower than at present.

On the continental shelf, there are also subcircular depressions with diameters ranging between 30 and $160 \mathrm{~m}$, and depths of 1.5-4 m: their bottoms are flat and smooth, and likely to be filled with fine sediments. These depressions could originate from the same processes responsible for the formation of the Gozitan sinkholes described in the previous section (Soldati et al. 2013; Galve et al. 2015), but more in-depth investigation is required to determine their cause and age of formation (Fig. 7).

\section{Northeastern sector of the submerged palaeolandscape}

The continental platform offshore of the NE Maltese archipelago is separated from the basin area by a 


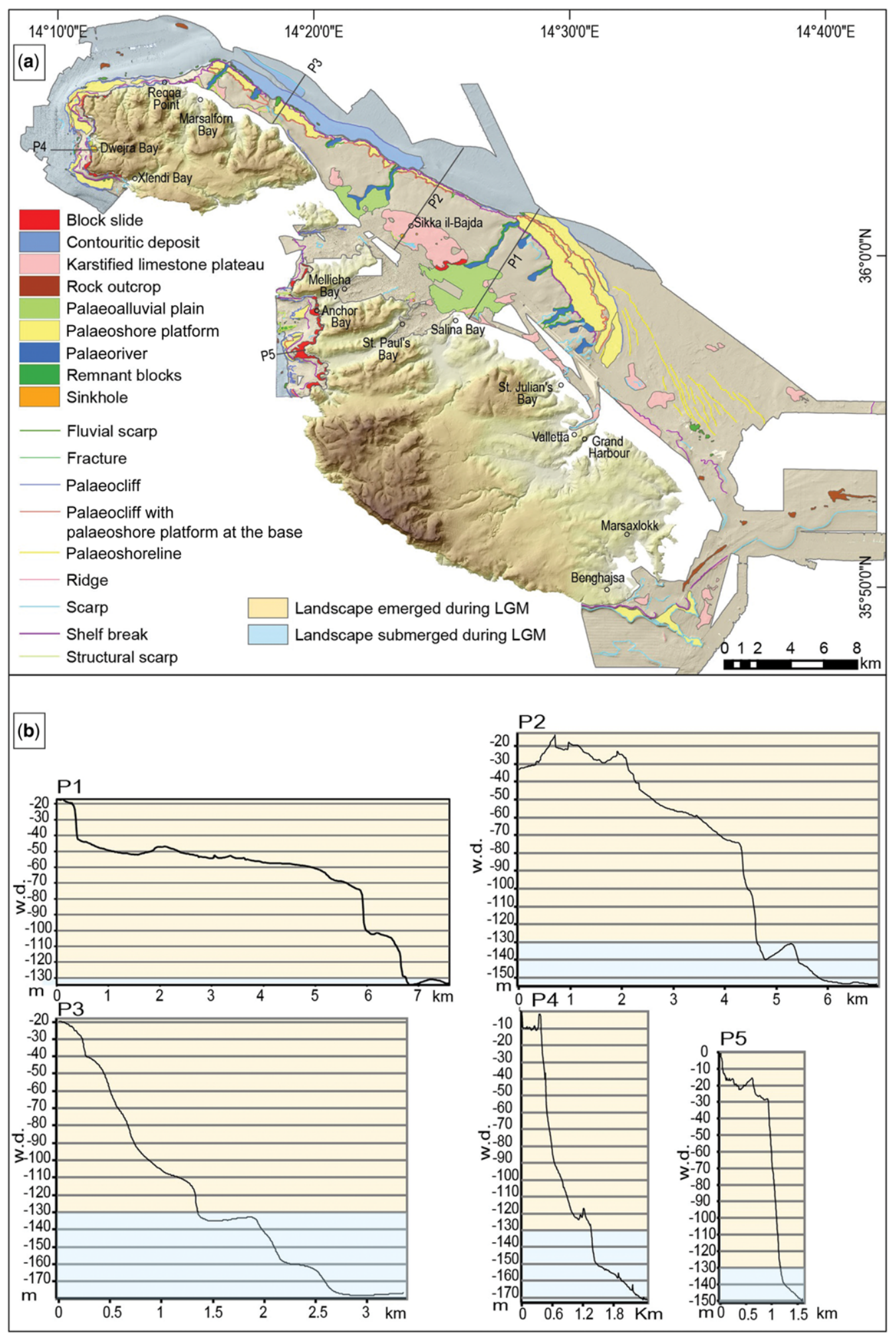


NW-SE-orientated escarpment. The shelf break ranges in depth between 70 and $95 \mathrm{~m}$. It is parallel to the present coastline and to the most recent fault system (NW-SE orientated), following the Pantelleria Rift trend, by which it is most likely to be controlled. The northern sector of the break of slope offshore of north Gozo, however, is parallel to the more ancient fault system (orientated ENE-WSW).

Clustered and isolated blocks punctuate parts of the seafloor downslope of the escarpment. The longest axis of the blocks ( $100 \mathrm{~m}$ long and $30 \mathrm{~m}$ wide) is generally parallel to the shoreline. They could represent limited rock-fall deposits or remnant blocks resulting from the differential erosion of the shelf break during the sea-level rise, similar to those previously described from the NW side of Malta.

Downslope of the escarpment, the seafloor is defined by flat terraces limited to landwards by concave breaks of slope. The latter have a similar orientation to the escarpment and occur at a depth of $108 \mathrm{~m}$; they range from 5 to $12 \mathrm{~km}$ in length and from 800 to $1000 \mathrm{~m}$ in width. The sediment covering the area consists of fine silty sand with a clayey fraction. The enlargement of the platform and its increase in depth southwards is probably due to a change in lithology from the harder Lower Coralline Limestone to the softer Globigerina Limestone (Micallef et al. 2013). These marine terraces were probably formed by subaerial weathering and wave erosion during lower sea levels (Micallef et al. 2013). The dominant sediment-type occurring on the shelf is medium and fine sand, occasionally grading to silt closer to the coast. Coarse sediment can be found from depths of 60 to $130 \mathrm{~m}$; sediment is often bioclastic-rich, being composed of calcareous red algae that form the distinct 'maërl' facies (Sciberras et al. 2009).

Several types of geomorphic feature occur on the continental shelf, including a karstified limestone plateau, tube-shape fissures, sinkholes and channels (Fig. 8). The Sikka Il-Bajda plateau is a gently sloping, moderately elevated area located on the shelf. It is marked by an irregular surface with tube-shape fissures that are very similar to those observed on land and developed in Globigerina Limestone. This plateau has been interpreted as a karstified pavement shaped in subaerial conditions during sea-level lowstands (Micallef et al. 2013).
The plateau is marked by subcircular depressions with diameters ranging from 60 to $270 \mathrm{~m}$ and almost vertical walls reaching up to $11 \mathrm{~m}$ in height (Micallef et al. 2013). The bottom of these depressions, at present covered by a Posidonia oceanica mat of vegetation, is peppered by rocky blocks, or draped by medium-fine sand appearing as a flat and smooth surface. Considering their regular shape, their dimensions, their fill and the presence of radial fractures, these presumed sinkholes seem to correspond fairly well to those described by Coratza et al. (2012), Soldati et al. (2013) and Galve et al. (2015) in Gozo. Thus, they could share a similar origin and, perhaps, age, but this hypothesis still requires further investigation (Fig. 9). As with analogue situations identified elsewhere on submerged limestone in other regions of the Mediterranean continental shelf, we cannot exclude that such sinkhole depressions might have hosted during Pleistocene times periodic stands of freshwater (cf. Taviani et al. 2012). Similar considerations may be extended to other now-drowned karstic depressions in Malta, such as those previously described for Dwejra Bay and Dwejra North. Ultimately, the coexistence of permeable v. impermeable bedrock lithologies, rock bedding, faulting and tilting in the Maltese archipelago might have favoured considerable freshwater circulation and accumulation under a scenario of wetter-than-present climate at certain times in the late Pleistocene.

Numerous SW-NE-orientated channels, ranging in length from $100 \mathrm{~m}$ to almost $4 \mathrm{~km}$, carve the platform between Marsalforn and St. Julian's. They have a U-shaped cross-section filled with up to $10 \mathrm{~m}$ of medium-fine sediment and a linear to sinuous pattern. The base of the channels becomes gradually deeper seawards, reaching a maximum depth of $90-130 \mathrm{~m}$, where their mouths are located (Micallef et al. 2013). The major channels, located offshore of Comino, start from a flat muddy area nearer the coast, interpreted as a former nowsubmerged alluvial plain, and cut the escarpment seawards. Many of these channels correspond to 'wied' and valleys on land: thus, they have been interpreted as their prolongation below present sea level. It is likely that the major and minor channels acted as river valleys and as shallow gullies, respectively. Both of these are likely to have formed during lower sea levels, such as during the LGM lowstand, when they reached their maximum

Fig. 4. (a) Map of the submerged palaeolandscape of the Maltese archipelago. The brownish area represents the landscape emerged during the LGM and the grey area indicates the areas submerged during the LGM. Most of the actual continental shelf was emerged during the LGM and it is characterized by a wide variety of terrestrial and marine geomorphic features of different genesis. (b) Bathymetric profiles across the shelf edge showing the different morphological configurations of the LGM palaeoshoreline (located at $-130 \mathrm{~m}$ ). As in (a), the grey area in the profiles shows the features submerged during the LGM and the brownish area the features emerged during the LGM. Profile locations are given in (a). 

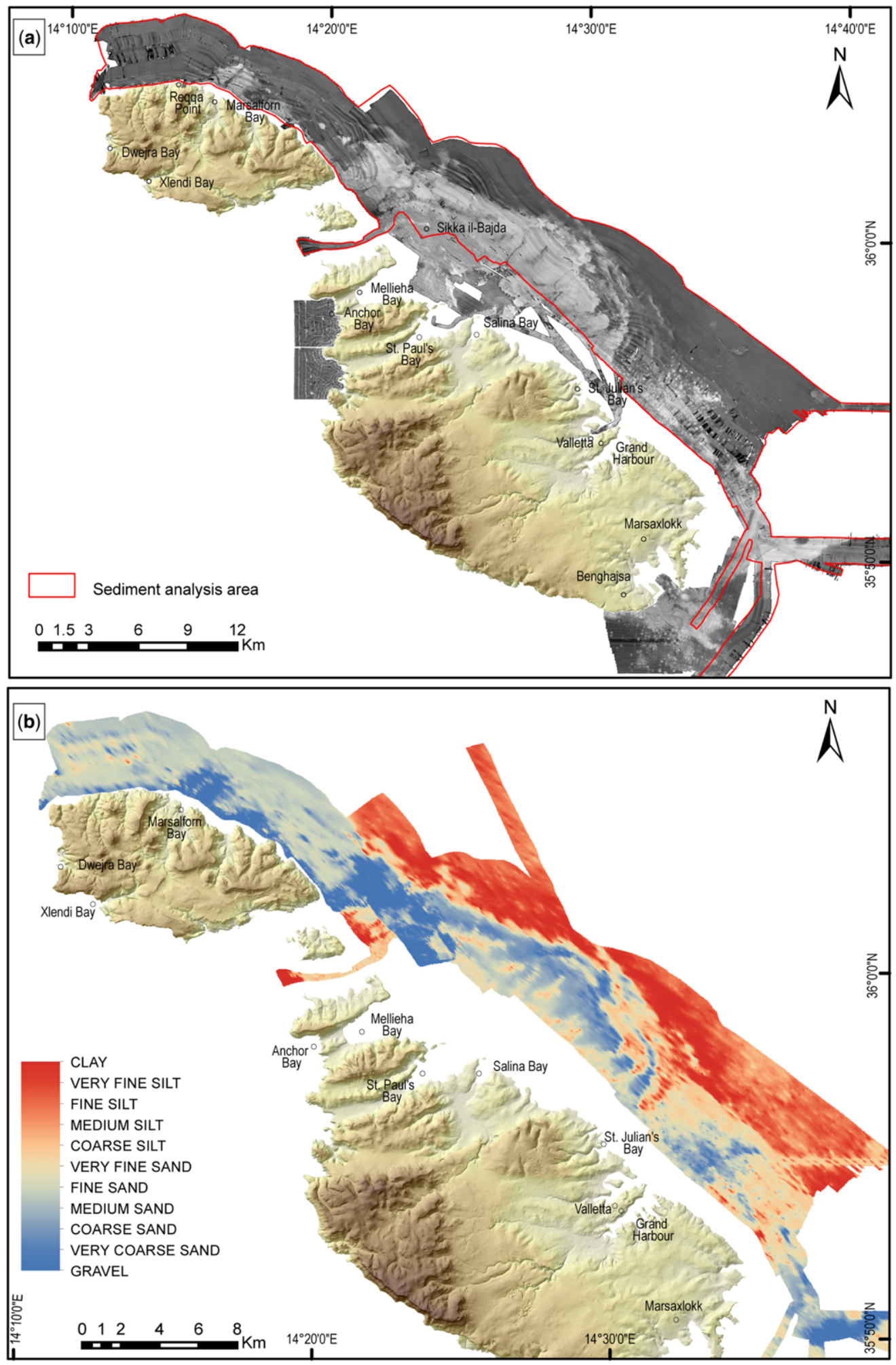

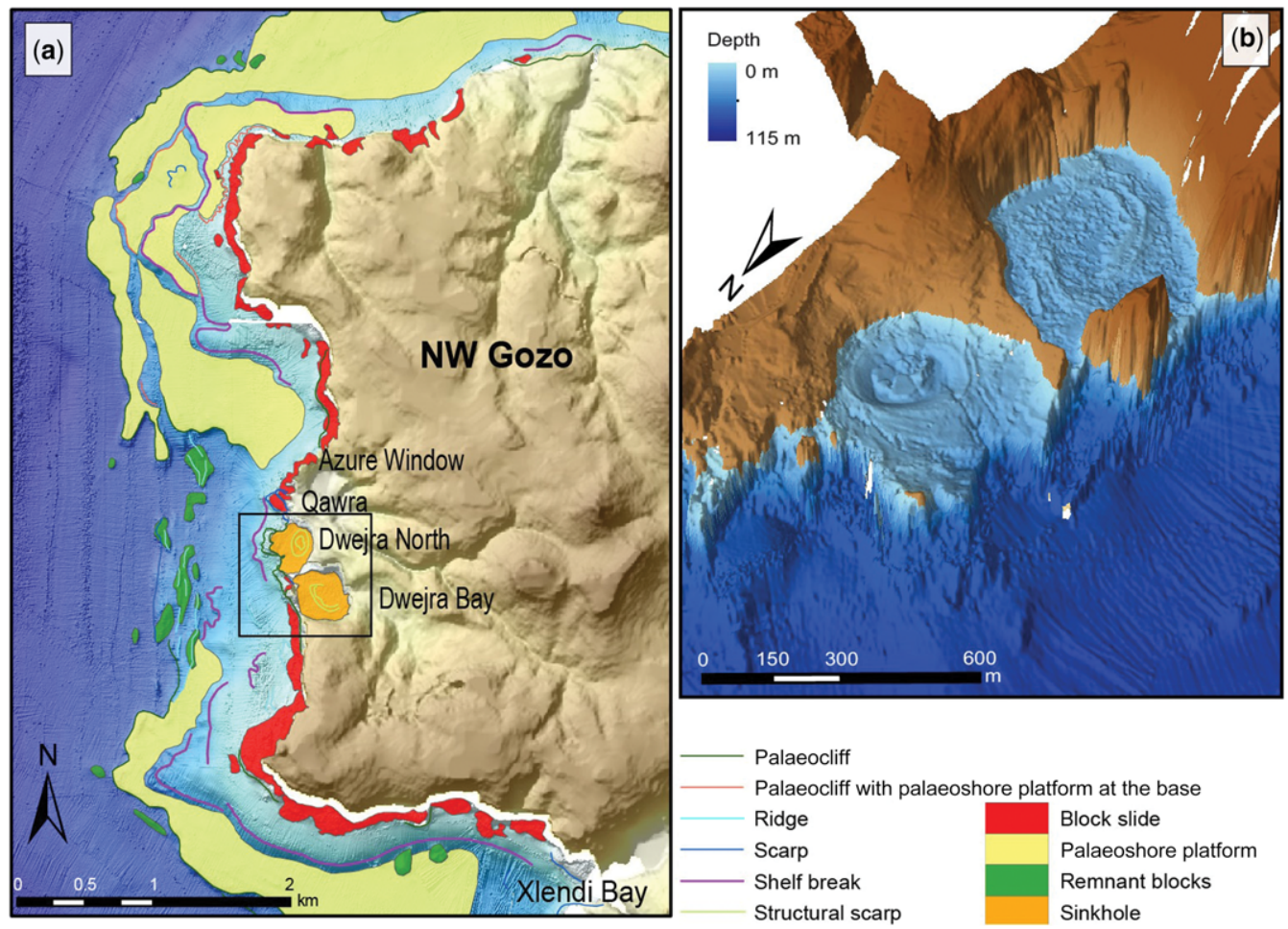

Fig. 6. (a) Detailed map of the submerged palaeolandscape of the western sector of Gozo. (b) Three-dimensional (3D) view of the Dwejra Bay and Dwejra North depressions interpreted as palaeosinkholes (grid resolution of $1 \mathrm{~m}$ and vertical exaggeration of $\times 5$ ).

development extending down to $130 \mathrm{~m}$ below present sea level (Micallef et al. 2013).

A series of ridges run parallel to the coastline at a depth of $100-120 \mathrm{~m}$ in the area in front of Valletta and the Grand Harbour (Fig. 4). The ridges are approximately $3-5 \mathrm{~km}$ long, $5 \mathrm{~m}$ high, are gently sloping $\left(0.3^{\circ}\right)$, slightly arched and mostly rectilinear in shape. The central part of this area is draped with coarse sediments up to gravel size, and calcarenitic blocks attributable to the Globigerina Limestone Formation, while the periphery comprises fine sediments (Fig. 5). Blocks may have been laid down here through the Wied il-Kbir Valley system that drained into the Grand Harbour during the post-glacial marine transgression and/ or in response to other marine processes such as shore-parallel currents. According to Micallef et al. (2013), these ridges could represent palaeoshoreline deposits, possibly aeolianites or marine-terrace deposits, and it is plausible that they represent the stages of the sea level during the post-glacial transgression.

Backscatter data show that in the central area immediately in front of Valletta's Grand Harbour there are a series of strips and roughly circular areas with a medium diameter of $100 \mathrm{~m}$. These elements are not typical of any known morphological feature. They could represent dredging spoils and hopper discharge consisting of a mixture of non-consolidated and coarse sediment with blocks of calcarenite.

\section{Southeastern sector of the submerged palaeolandscape}

Offshore of SE Malta, the platform area extends down to a depth of $130 \mathrm{~m}$ and is separated from the

Fig. 5. (a) Backscatter grid derived from MBES data and (b) results of the sediment analysis performed in the red box area indicated in (a) using the CARIS HIPS and SIPS 'Auto Analyze' tool. The sediment analysis determined the type of sediment, classifying the grain size by the angular response of the backscatter data, as illustrated in Fonseca \& Calder (2007) and Fonseca \& Mayer (2007). 

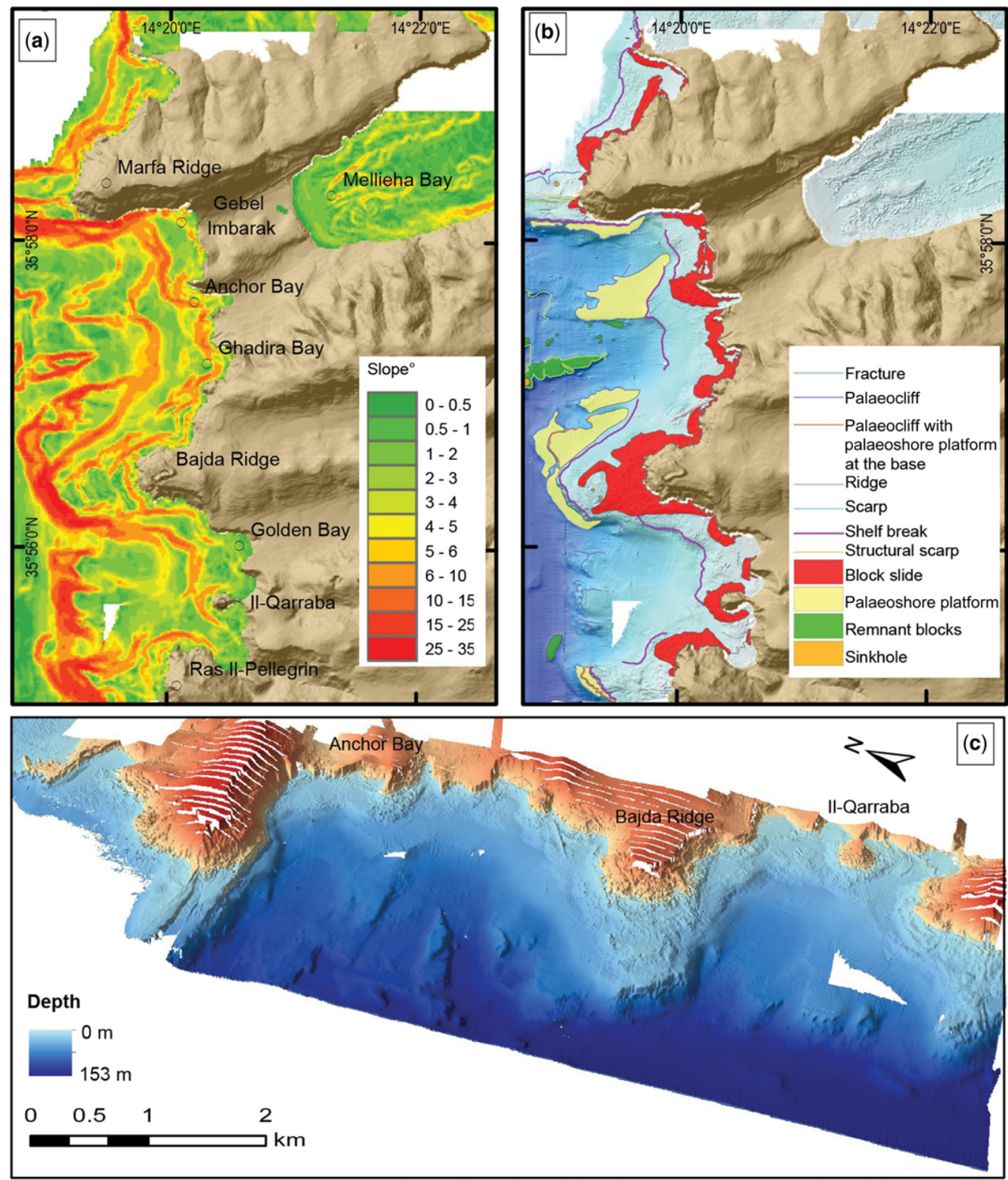

Fig. 7. (a) Slope map and (b) detailed map of the submerged palaeolandscape of the NW sector of Malta characterized by extensive coastal landslides. (c) Three-dimensional (3D) bathymetric view of the seafloor and land. Terrestrial data come from LiDAR, with a resolution of $1 \mathrm{~m}$ (vertical exaggeration of $\times 5$ ).

basin area by a break of slope (from $2^{\circ}$ to $7^{\circ}$ in gradient) that is located at a mean distance of $3 \mathrm{~km}$ from the coast. This platform shows a terraced structure that covers an area ranging from 0.3 to $2 \mathrm{~km}^{2}$ and a sediment cover that is likely to consist of fine and silty sand. These terraces are marked by escarpments ranging in slope from $20^{\circ}$ to $27^{\circ}$ in correspondence with Benghajsa Point, and from $5^{\circ}$ to $10^{\circ}$ in correspondence with the western sector of the area.

This system of escarpments runs in a NW-SE direction and is probably controlled by the youngest fault system parallel to the Maghlaq Fault (orientated NW-SE). Owing to their morphology and to their similarity with the SE Maltese platform, these escarpments have been interpreted as 


\section{DROWNED LANDSCAPES OF THE MALTESE ISLANDS}
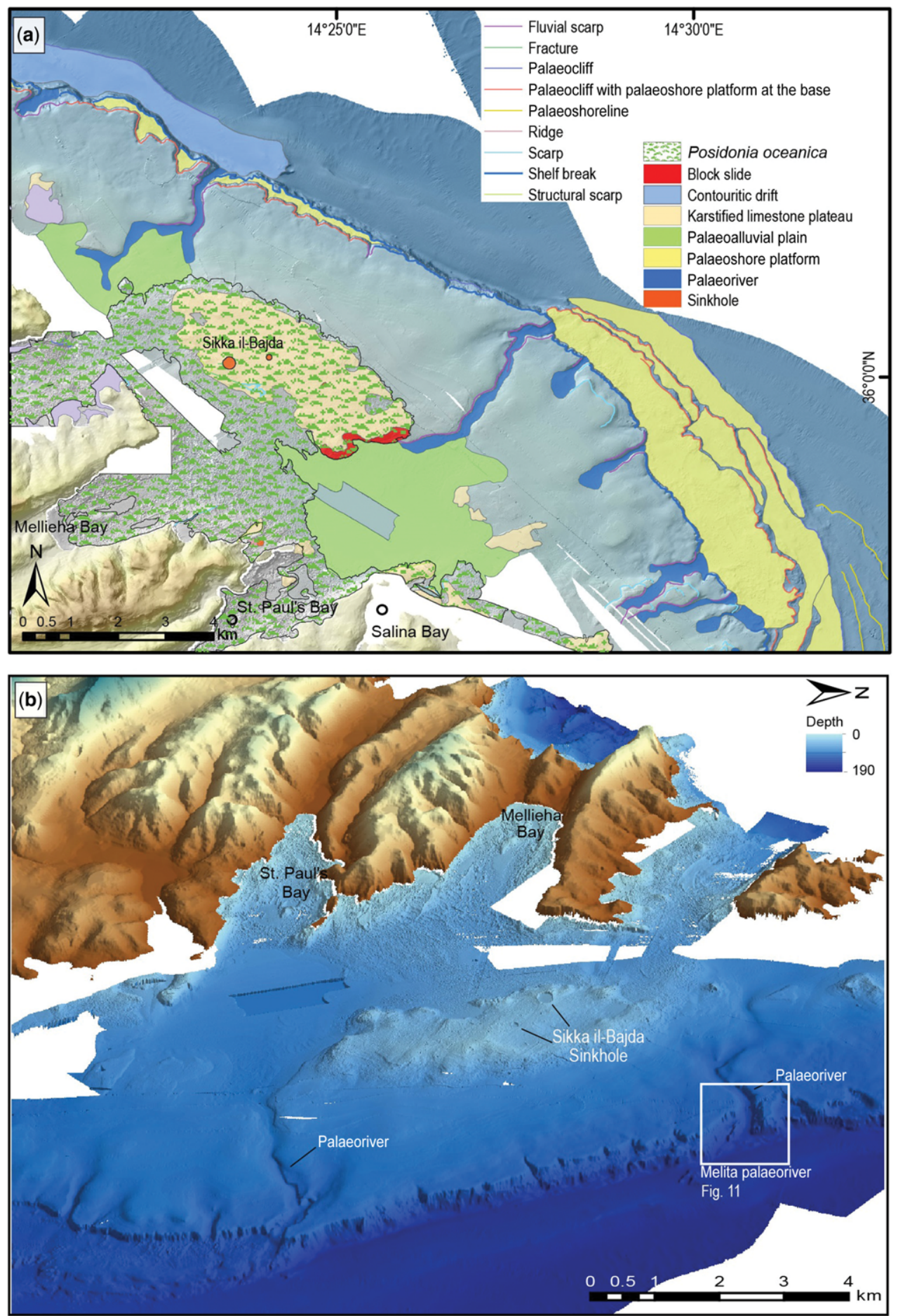

Fig. 8. (a) Detailed map of the submerged palaeolandscape of the NE sector of Malta. (b) Three-dimensional (3D) bathymetric view of the area where the most relevant palaeorivers and sinkholes were detected (grid resolution of $5 \mathrm{~m}$, vertical exaggeration of $\times 5$ ). 


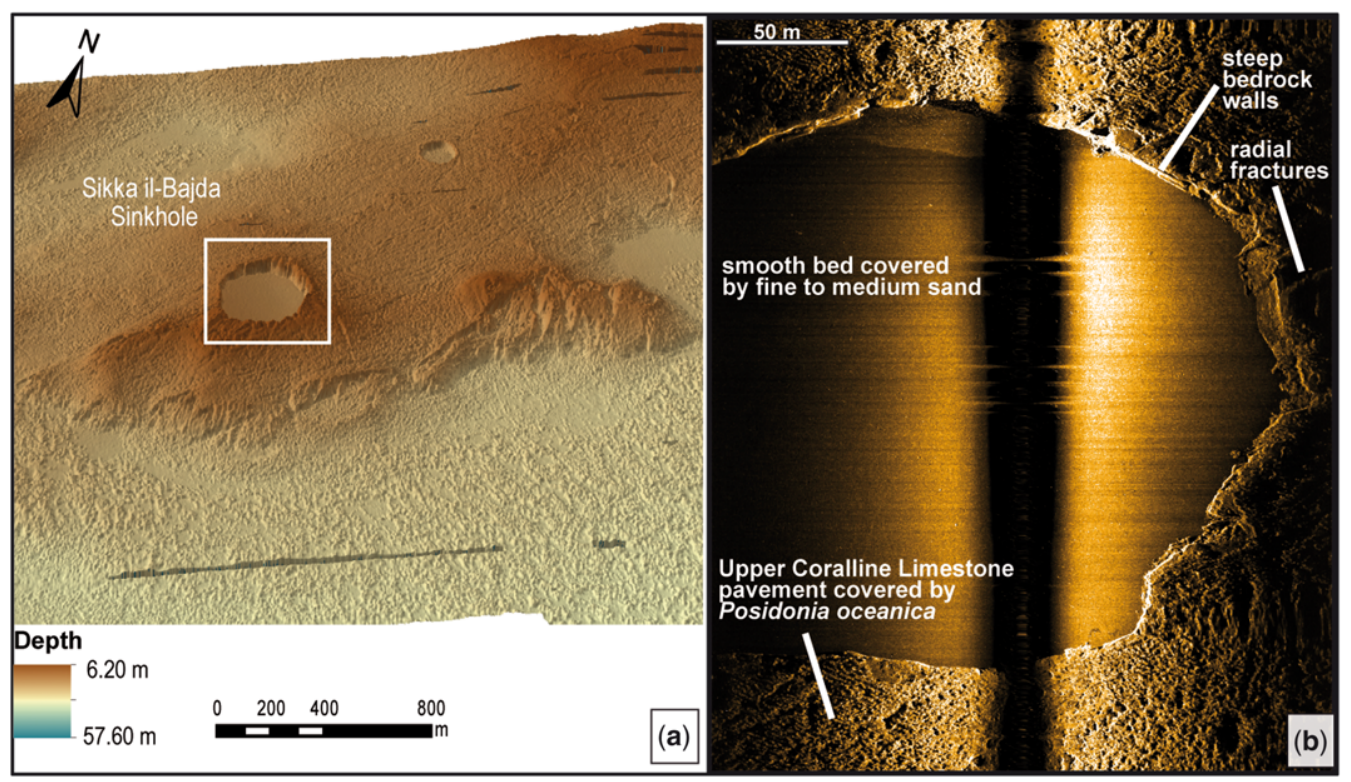

Fig. 9. Detail of the Sikka il-Bajda sinkhole located on the bedrock reef. (a) Three-dimensional (3D) bathymetric view (grid resolution of $1 \mathrm{~m}$, vertical exaggeration of $\times 5$ ). (b) High-resolution side-scan sonar image of the sinkhole located in (a).

fault-controlled palaeoshorelines formed by sealevel fluctuation.

In the area offshore of Benghajsa Point and Delimara Point, the platform stretches out to the SE and deepens in the centre, offshore of Marsaxlokk. This morphology is probably linked to the origin of Marsaxlokk Bay. According to Soldati et al. (2013), rounded bays in SE Malta have been generated in relation to old drainage lines. Retrogressive erosion at the outlet of meteoric water flow affected the more competent rocks belonging to the Upper Coralline Limestone. The cove was modelled through the action of wave refraction as soon as the softer rocks pertaining to the Middle Globigerina Limestone were reached by the sea (Soldati et al. 2013). In the distal platform (from 50 down to $120 \mathrm{~m}$ ) there are several outcrops and circular features related to dredge spoils similar to those in Valletta harbour. An ENE-WSW linear feature running for $4.6 \mathrm{~km}$ in the area of Peter's Pool is interpreted here as a tectonic feature likely to be related to the oldest parallel fault system.

\section{Submergence of the Maltese palaeolandscape after the Last Glacial Maximum}

In view of the relative stability of the Maltese Islands during the Last Glacial Cycle and the Holocene
(Furlani et al. 2013), we use the relative sea-level change curve for the site of Pantani Cuba and Longarini, which is the closest site to the Maltese Islands in the south of Sicily (Lambeck et al. 2011), to understand how the palaeolandscape has been drowned by sea-level rise since the LGM.

The maximum exposure of the Maltese Islands occurred at $20 \mathrm{ka}$, when the sea level was at $-130 \mathrm{~m}$ (Fig. 10). At this point, the entire archipelago was connected and a land bridge $-90 \mathrm{~km}$ long and $40 \mathrm{~km}$ wide - extended from the SE of Malta to the south of Sicily. Sea-level rise due to climatic amelioration after the LGM submerged the Maltese palaeolandscape at an average rate of $5 \mathrm{~mm} \mathrm{a}^{-1}$ (Lambeck et al. 2011). By $14.4 \mathrm{ka}$, the sea level had dropped to $-100 \mathrm{~m}$. The land bridge had narrowed to less than $10 \mathrm{~km}$ and a good part of the shore platform associated with the $-130 \mathrm{~m}$ palaeoshoreline had been drowned. By $12.9 \mathrm{ka}$, the land bridge had become largely submerged and the Maltese archipelago became disconnected from Sicily; the archipelago at this time had an area of $720 \mathrm{~km}^{2}$, which is more than twice the present surface area. The islands of Malta, Gozo and Comino were connected until $8.6 \mathrm{ka}$, when the Sikka l-Bajda limestone plateau became an island. Sea-level rise during the following few thousand years submerged the remaining $65 \mathrm{~km}^{2}$ of palaeolandscape to give rise to the current configuration of the Maltese Islands. 

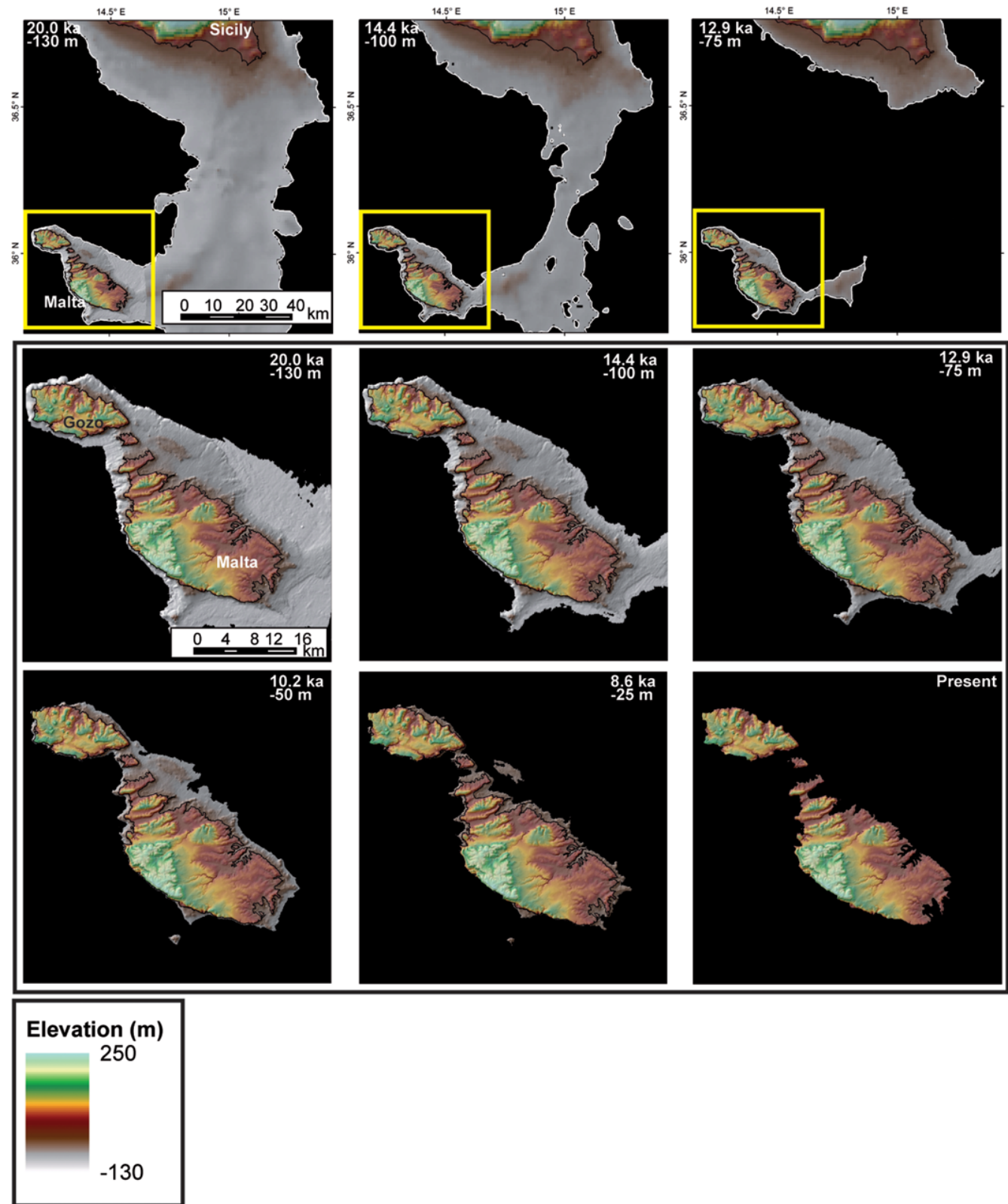

Fig. 10. Reconstruction of the evolution of the Maltese palaeolandscape after the LGM from 20 ka until present. In the upper part of the figure, the land bridge connecting Sicily to Malta during the LGM is visible.

\section{Implications for prehistoric investigations}

The main ambition of the present study is to provide reliable pre-inundation topographical and environmental information useful to any future archaeological-prehistorical exploration of the Maltese shelf.
An important aspect of such a study is that the former subaerial landscape as it exists on the presentday seabed has been more or less profoundly altered and masked by marine processes, whether erosional, accretional or depositional.

However, as shown by our geomarine documentation, sectors of the Maltese margin still retain 


\section{F. FOGLINI $E T A L$.}

recognizable features related to their former subaerial environments.

It is reasonable to infer that many such late Pleistocene submerged areas were colonized by terrestrial fauna and vegetation. The Maltese archipelago boasts a significant legacy of prehistoric life encompassing the last Pleistocene Ice Age, as testified by a number of deposits on land (Zammit Maepel 1985; Savona-Ventura \& Mifsud 1998; Hunt \& Schembri 1999; Marra 2005). The contiguity with the Sicilian block at the time of lowest relative sea levels implies at least partial overlapping of their faunal elements (Cassar et al. 2008; Palombo et al. 2008).

By combining this palaeontological evidence with palaeoenvironments identified during our survey, it is not unrealistic to propose that the fluvial areas and their alluvial deposits, probably rimmed by deciduous woodlands, provided a suitable habitat for terrestrial megafauna such as deer, horse, bear, wolf, fox and other mammals, possibly including endemic elephants (Fig. 11). All of this fauna, however, became extinct by the end of the
Pleistocene (Gliozzi et al. 1983; Hunt \& Schembri 1999; Marra 2005; Massetti 1995; Palombo 2007; Masini et al. 2008; Palombo \& Rozzi 2013).

However, potential frequentation by Pleistocene humans, although likely when considering the palaeogeography of the Sicilian-Maltese block (Palombo 2010; Furlani et al. 2013), is not substantiated thus far by any direct evidence, neither under water nor on land in the Maltese archipelago. The oldest documentation of humans on the Maltese archipelago dates back to the megalithic culture about 5 ka BP (Anati \& Anati 1988; Flemming et al. 2003; Marriner et al. 2012), by which time sea level had reached roughly its present position (Siddall et al. 2003).

Our exercise, therefore, is no more than a first step in helping prehistorians to select sites of potential significance. The identification of former riverine habitats (e.g. the Melita palaeoriver: Fig. 11) may call for a careful and focused exploration of these areas in the search for fossils and/or artefacts. Similar arguments may also be applied to the karst depressions, by analogy with what is often seen on

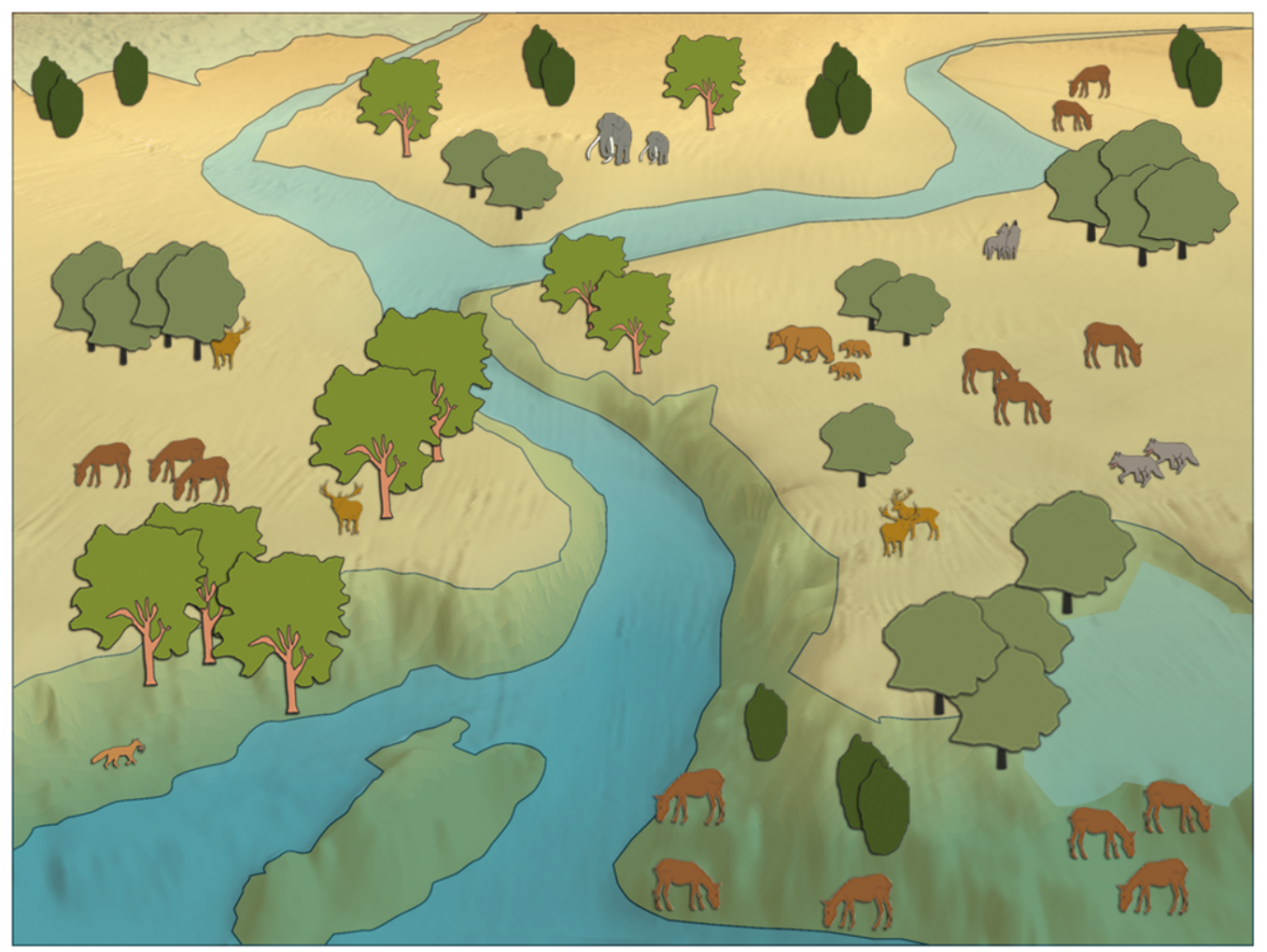

Fig. 11. Artistic reconstruction of a plausible landscape at the time of the LGM around a former river, here named Melita palaeoriver (location given in Fig. 8b). Fauna and flora has been inspired by late Pleistocene Maltese palaeontological data (e.g. Hunt 1997; Hunt \& Schembri 1999). 
land. Obviously, almost none of these features are now easily accessible to inspection for prehistoric purposes because they has been, in one way or another, modified by marine processes and often draped or infilled by sediments. However, our detailed maps of former landscapes will hopefully be instrumental in planning the type of methodology and the best exploratory techniques for future underwater archaeological investigation.

Future geomarine work clearly should aim to fill gaps in the areal coverage not only of the Maltese archipelago sensu stricto, especially the western side that is still largely uncharted, but also expand into the remaining part of the wide Siculo-Tunisian shelf, which has only been minimally mapped to date.

This research was supported by the European projects HERMIONE (grant agreement No. 226354) COCONET (grant agreement No. 287844) and SCARP (grant agreement No. PCIG13-GA-2013-618149) within the European Community's 7th Framework Programme (FP7 2007-2013), and PANACEA, funded under the ItalyMalta 2007-2013 Operational Programme I. We kindly acknowledge the RPM Nautical Foundation, the captain and crew of R/V Hercules and R/V Urania, and Highland Geo Solutions for their assistance with data collection. We are grateful to 'AquaBioTech Group' for providing access to high-resolution LiDAR data, and to the Hydrographic Office of the Malta Maritime Authority and the UK Hydrographic Office for providing access to the singlebeam echosounder data of the Maltese coastal waters and the HMS Roebuck MBES dataset. These data contain public sector information, licensed under the Open Government Licence v2.0; they have been reproduced by permission of the Controller of Her Majesty's Stationery Office and the UK Hydrographic Office, and they should not be used for navigation. The MBES, ROV, grab and SCUBA dive surveys were made possible by permits issued by the Malta Resources Authority and the Environment Protection Directorate of the Malta Environment and Planning Authority. We would like to thank Timothy Le Bas for helping with data processing. This research contributes to the RITMARE Project and is ISMARBologna Scientific Contribution No. 1806.

The work was carried out within the project MAPSCAPE (Mapping the Quaternary landscape of the Maltese Islands) and is also part of COST (Cooperation in European Science and Technology) Action TD0902 SPLASHCOS (Submerged Prehistoric Archaeology and Landscapes of the Continental Shelf), funded by the ESF through the EU RTD Framework Programme. This study is also part of the Project 'Coupling terrestrial and marine datasets for coastal hazard assessment and risk reduction in changing environments' funded by the EUR-OPA Major Hazards Agreement of the Council of Europe (2012-2015).

\section{References}

AleXANDER, D. 1988. A review of the physical geography of Malta and its significance for tectonic geomorphology. Quaternary Science Reviews, 7, 41-53.
Anati, A. F. \& AnAti, E. 1988. Missione a Malta: ricerche e studi sulla preistoria dell'arcipelago maltese nel contesto mediterraneo. Jaca Books, Milan.

Anderson, E. W. 1997. The wied: a representative Mediterranean landform. GeoJournal, 41(2), 111-114.

Antonioli, F., Lo Presti, V. ex al. 2014. Timing of the emergence of the Europe-Sicily bridge (40-17 cal ka BP) and its implications for the spread of modern humans. In: HARFF, J., BAILEY, G. \& LÜTH, F. (eds) Geology and Archaeology: Submerged Landscapes of the Continental Shelf. Geological Society, London, Special Publications, 411. First published on September 11, 2014, http://doi.org/10.1144/SP411.1

Argnani, A. 1990. The Strait of Sicily rift zone: foreland deformation related to the evolution of a back-arc basin. Journal of Geodynamics, 12, 311-331.

Bailey, G. N. \& Flemming, N. C. 2008. Archaeology of the continental shelf: marine resources, submerged landscapes and underwater archaeology. Quaternary Science Reviews, 27, 2153-2165.

Benjamin, J. 2010. Submerged prehistoric landscapes and underwater site discovery: reevaluating the 'Danish Model' for International Practice. The Journal of Island and Coastal Archaeology, 5, 253-270.

Benjamin, J., Bonsall, C., Pickard, C. \& Fischer, A. 2011. Underwater Archaeology and the Submerged Prehistory of Europe. Oxbow, Oxford.

BICKet, A. 2011. Submerged Prehistory: Marine ALSF Research in Context. Marine ALSF Science Monograph Series, 5.

Biolchi, S., Furlani, S., Devoto, S., Gauci, R., Castaldini, D., Soldati, M. 2015. Geomorphological identification, classification and spatial distribution of coastal landforms of Malta (Mediterranean Sea). Journal of Maps, 11, http://doi.org/10.1080/ 17445647.2014.984001

Bowen-Jones, H., Dewdney, J. \& Fisher, W. 1961. Malta: Background for Development. University of Durham Press, Durham.

Carroll, F. A., Hunt, C. O., Schembri, P. J. \& Bonanno, A. 2012. Holocene climate change, vegetation history and human impact in the Central Mediterranean: evidence from the Maltese Islands. Quaternary Science Reviews, 52, 24-40.

Cassar, L. F., Conrad, E. \& Schembri, P. J. 2008. The Maltese Archipelago. In: Vogiatzakis, I. N., PUGNetTi, G. \& Mannion, A. M. (eds) Mediterranean Island Landscapes: Natural and Cultural Approaches. Springer, Berlin, 297-322.

Catalano, S., De Guidi, G., Romagnoli, G., Torrisi, S., Tortorici, G. \& Tortorici, L. 2008. The migration of plate boundaries in SE Sicily: influence on the large-scale kinematic model of the African promontory in southern Italy. Tectonophysics, 449, 41-62.

Cello, G. 1987. Structure and deformation processes in the Strait of Sicily 'rift zone'. Tectonophysics, 141, 237-247.

Civile, D., Lodolo, E., Accettella, D., Geletti, R., Ben-Avraham, Z. \& Deponte, M. 2010. The Pantelleria graben (Sicily Channel, Central Mediterranean): an example of intraplate passive rift. Tectonophysics, 490, 173-183.

Coratza, P., Bruschi, V. M., Piacentini, D., Saliba, D. \& Soldati, M. 2011. Recognition and Assessment of 


\section{F. FOGLINI ET AL.}

Geomorphosites in Malta at the Il-Majjistral Nature and History Park. Geoheritage, 3, 175-185.

Coratza, P., Galve, J. P., Soldati, M. \& Tonelli, C. 2012. Recognition and assessment of sinkholes as geosites: lessons from the Island of Gozo (Malta). Quaestiones Geographicae, 31, 27-37.

Dart, C. J., Bosence, W. J. \& McClay, K. R. 1993. Statigraphy and structure of the Maltese graben system. Journal of Geological Society, London, 150, 1153-1166, http://doi.org/10.1144/gsjgs.150.6.1153

De Falco, G., Ferrari, S., Cancemi, G. \& Baroli, M. 2000. Relationship between sediment distribution and Posidonia oceanica seagrass. Geo-Marine Letters, 20, 50-57.

Devoto, S. 2013. Cartografia, monitoraggio e modellizzazione di frane lungo la costa nord-occidentale dell'isola di Malta. $\mathrm{PhD}$ thesis, University of Modena and Reggio Emilia, Italy.

Devoto, S., Biolchi, S. ET AL. 2012. Geomorphological map of the NW Coast of the Island of Malta (Mediterranean Sea). Journal of Maps, 8, 33-40.

Devoto, S., Biolchi, S., Bruschi, V. M., Díez, A. G., Mantovani, M., Pasuto, A. \& Soldati, M. 2013. Landslides along the north-west coast of the Island of Malta. In: Margottini, C., Canuti, C. \& Sassa, K. (eds) Landslide Science and Practice, Volume 2. Springer, Berlin, 57-63.

DYKes, A. P. 2002. Mass movements and conservation management in Malta. Journal of Environmental Management, 66, 77-89.

FARrugia, M. T. 2008. Coastal erosion along the northern Malta: geomorphological processes and risks. Geografia Fisica e Dinamica Quaternaria, 31, 149-160.

Flemming, N. C. 1969. Archaeological Evidence for Eustatic Change of Sea Level and Earth Movements in the Western Mediterranean During the Last 2000 Years. Geological Society of America, Special Papers, 109.

Flemming, N. C., Bailey, G. N., Courtillot, V., King, G., LAMBeCK, K., Ryerson, F. \& Vita-FinZI, C. 2003. Coastal and marine palaeo-environments and human dispersal points across the Africa-Eurasia boundary. In: BrebBia, C. A. \& Gambien, T. (eds) Maritime Heritage. Wessex Institute of Technology, Southampton, 61-74.

Fonseca, L. \& CAlder, B. 2007. Clustering acoustic backscatter in the angular response space. In: Proceedings of the United States Hydrographic Conference, Norfolk, VA, 15-17 May 2007, http://www.thsoa. org/hy07/06_02.pdf

Fonseca, L. \& MAYER, L. 2007. Remote estimation of surficial seafloor properties through the application Angular Range Analysis to multibeam sonar data. Marine Geophysical Researches, 28, 119-126.

Furlani, S., Antonioli, F. ET AL. 2013. Holocene sea level change in Malta. Quaternary International, 288, 146-157.

GaleA, P. 2007. Seismic history of the Maltese Islands and considerations on seismic risk. Annals of Geophysics, 50, 725-740.

Galve, J. P., Tonelli, C., Gutiérrez, F., Lugli, S., Vescogni, A. \& Soldati, M. 2015. New insights into the genesis of the Miocene collapse structures of the Island of Gozo (Malta, central Mediterranean Sea).
Journal of the Geological Society, London, 172, 336-348, http://doi.org/10.1144/jgs2014-074

Gliozzi, E., Malatesta, A. \& Scalone, E. 1983. Revision of Cervus elaphus siciliae Pohlig, 1893, Late Pleistocene endemic deer of the siculo-maltese district. Geologica Romana, 29, 307-353.

Hunt, C. O. 1997. Quaternary deposits in Maltese Islands: a microcosm of environmental change in Mediterranean lands. GeoJournal, 41(2), 101-109.

Hunt, C. O. \& Schembri, P. J. 1999. Quaternary environments and biogeography of the Maltese Islands. In: Mifsud, A. \& Savona-Ventura, C. (eds) Facets of Maltese Prehistory. The Prehistoric Society of Malta, Malta, 41-75.

ILLIES, J. H. 1981. Graben formation -The Maltese IslandsA case history. Tectonophysics, 73, 151-168.

Jongsma, D., Van Hinte, E. J. \& Woodside, J. M. 1985. Geologic structure and neotectonics of the North African Continental Margin south of Sicily. Marine and Petroleum Geology, 2, 156-179.

Lambeck, K. \& Purcell, A. 2005. Sea-level change in the Mediterranean Sea since the LGM: model predictions for tectonically stable areas. Quaternary Science Reviews, 24, 1969-1988.

Lambeck, K., Antonioli, F., Anzidei, M., Ferranti, L., Leoni, G. \& Silenzi, S. 2011. Sea level change along the Italian coasts during Holocene and prediction for the future. Quaternary International, 232, 250-257.

Le Bas, T. P. \& Hühnerbach, V. 1998. PRISM Processing of Remotely-sensed Imagery for Seafloor Mapping Handbook. Southampton Oceanography Centre Report.

MAGRI, O. 2006. A geological and geomorphological review of the Maltese Islands with special reference to the coastal zone. Territoris, 6, 7-26.

Magri, O., Mantovani, M., Pasuto, A. \& Soldati, M. 2008. Geomorphological investigation and monitoring of lateral spreading along the north-west coast of Malta. Geografia Fisica e Dinamica Quaternaria, 31, $171-180$.

Mantovani, M., Devoto, S., Forte, E., Mocnik, A., Pasuto, A., Piacentini, D. \& Soldati, M. 2013. A multidisciplinary approach for rock spreading and block sliding investigation in the north-western coast of Malta. Landslides, 10, 611-622.

Marra, A. C. 2005. Pleistocene mammals of Mediterranean islands. Quaternary International, 129, 5-14.

Marriner, N., Gambin, T., Duamali, M., Morhange, C. \& SPITERI, M. 2012. Geoarchaeology of the Burmarrad ria and early Holocene human impacts in western Malta. Palaeogeography, Palaeoclimatology, Palaeoecology, 339-341, 52-65.

Masetti, G., Sacile, R. \& Trucco, A. 2010. Caratterizzazione remota del fondale marino tramite analisi e mosaicatura del backscatter. In: Atti 14a Conferenza Nazionale ASITA, Brescia, 9-12 Novembre 2010. Associazione Italiana per le Informazioni Territoriali e Ambientali, 1275-1280.

Masini, F., Petruso, D., Bonfiglio, L. \& Mangano, G. 2008. Origination and extinction patterns of mammals in three central Western Mediterranean islands from the Late Miocene to Quaternary. Quaternary International, 182, 63-79. 


\section{DROWNED LANDSCAPES OF THE MALTESE ISLANDS}

Massetti, M. 1995. Quaternary biogeography of the Mustelidae family on the Mediterranean islands. Hystrix, 7, 17-34.

Micallef, A., Foglini, F., Le Bas, T., Angeletti, L., Maselli, V., Pasuto, A. \& Taviani, M. 2013. The submerged palaeolandscape of the Maltese Islands: morphology evolution and relation to Quaternary environmental change. Marine Geology, 335, 129-147.

Oil Exploration Directorate 1993. Geological Map of the Maltese Islands. Sheet 1. Malta, Scale 1:25,000. Office of the Prime Minister, Valletta, Malta.

Palombo, M. R. 2007. How can endemic proboscideans help us understand the "island rule"? A case study of Mediterranean islands. Quaternary International, 169-170, 105-124.

PAlombo, M. R. 2010. A scenario of human dispersal in the northwestern Mediterranean throughout the Early to Middle Pleistocene. Quaternary International, 223-224, 179-194.

Palombo, M. R. \& Rozzi, R. 2013. Chapter 4. Dwarfing and gigantism in Quaternary vertebrates. In: ELIAS, S. A. \& Mock, C. (eds) The Encyclopedia of Quaternary Science. Elsevier, Amsterdam, 733-747.

Palombo, M. R., Sardella, R. \& Novelli, M. 2008. Carnivora dispersal in western Mediterranean during the last 2.6 Ma. Quaternary International, 179, $176-189$.

Paskoff, R. \& Sanlaville, P. 1978. Observations geomorphologiques sur les côtes de l'archipel Maltais. Zeitschrift für Geomorphologie, 22, 310-328.

Pedley, H. M. 1974. Miocene sea-floor and later subaerial solution subsidence structures in the Maltese Islands. Proceedings of the Geologists' Association, 85, 533-547.

Pedley, H. M. 2011. The Calabrian Stage, Pleistocene highstand in Malta: a new marker for unravelling the Late Neogene and Quaternary history of the islands. Journal of the Geological Society, London, 168, 913-925, http://doi.org/10.1144/0016-76492010-080

Pedley, H. M., Clarke, M. H. \& Galea, P. 2002. Limestone Isles in a crystal: The Geology of the Maltese Islands. Publisher Enterprises Group, Malta.

Prampolini, M. 2012. Analisi geomorfologica di aree di piattaforma continentale dell'arcipelago maltese tramite l'utilizzo di dati MultiBeam. MSc thesis, University of Modena and Reggio Emilia.

Prampolini, M. 2013. Integrazione di dati a terra e a mare per una cartografia geomorfologica della costa NW dell'isola di Malta. In: Del Monte, M. (ed.) Atti della V Giornata Nazionale dei Giovani Geomorfologi. ARACNE editrice, Rome, 61-64.

Putz-Perrier, M. W. \& Sanderson, D. J. 2010. Distribution of faults and extensional strain in fractured carbonates of the North Malta Graben. American Association of Petroleum Geologists Bulletin, 9, 435-456.

Reuther, C. D. \& Eisbacher, G. H. 1985. Pantelleria Rift crustal extension in a convergent intraplate setting. International Journal of Earth Sciences, 74, 585-597.

SAID, G. \& Schembri, P. J. 2010. Malta. In: Bird, E. C. F. (eds) Encyclopedia of the World's Coastal Landforms, Volume 1. Springer, Dordrecht, 751-759.

Savona-Ventura, C. \& Mifsud, A. 1998. Ghar Dalam cave: a review of the sediments on the cave floor stratigraphy. Xjenza (Malta), 3, 5-12.

Sciberras, M., Rizzo, M., Mifsud, J. R., Camilleri, K., Borg, J. A., Lanfranco, E. \& Schembri, P. J. 2009. Habitat structure and biological characteristics of a maerl bed off the northeastern coast of the Maltese Islands (central Mediterranean). Marine Biodiversity, 39, 251-264.

Serpelloni, E., Vannucci, G. et al. 2007. Kinematics of the Western Africa-Eurasia plate boundary from focal mechanisms and GPS data. Geophysics Journal International, 169, 1180-1200.

Siddall, M., Rohling, E. J., Almogi-Labin, A., Hemleben, C., Meischner, D., Schmelzer, I. \& Smeed, D. A. 2003. Sea-level fluctuations during the last glacial cycle. Nature, 423, 853-858.

Smith, W. H. F. \& SANDwell, D. T. 1997. Global seafloor topography from satellite altimetry and ship depth soundings. Science, 277, 1957-1962.

Soldati, M., Maquaire, O., Zezere, J. L., Piacentini, D. \& LissaK, C. 2011. Coastline at Risk: methods for Multi-Hazard Assessment. Journal of Coastal Research, Special Issue 61, 335-339.

Soldati, M., Tonelli, C. \& Galve, J. P. 2013. Geomorphological evolution of palaeosinkhole features in the Maltese Archipelago (Mediterranean Sea). Geografia Fisica e Dinamica Quaternaria, 36, 189-198.

Swift, D. J. P., Stanley, D. J. \& Curry, J. R. 1971. Relict sediment on continental shelves: a reconsideration. Journal of Geology, 79, 322-346.

Taviani, M., Angeletti, L. et al. 2012. Drowned karst landscape offshore the Apulian margin (Southern Adriatic Sea, Italy). Journal of Cave and Karst Studies, 74, 197-212.

Westley, K., Quinn, R., Forsythe, W. \& Plets, R. 2011. Mapping submerged landscapes using multibeam bathymetric data: a case study from the north coast of Ireland. International Journal of Nautical Archaeology, 40, 99-112.

ZAMmit MAEPEL, G. 1985. Biology and ecology of Ghar Dalam cave, Malta. Atti della Società Toscana di Scienze Naturali, Memorie, Serie A, 92, 351-374. 